\title{
Hangover relieving effect of Sanghwang mushroom mycelium cultured in germinated buckwheat
}

\author{
Yoo-Jin An ${ }^{1}$, Sung-Min Cho' ${ }^{1}$, Min-Su Kim ${ }^{1}$, Hae-Hee Moon ${ }^{1}$, Dong- Soo Park², \\ Nam-Gen Jeon ${ }^{2}$, Youngjae Lee ${ }^{1}$, Chang-Hoon Han ${ }^{1, *}$ \\ ${ }^{1}$ College of Veterinary Medicine, Jeju National University, Jeju 63243, Korea \\ ${ }^{2}$ Jeju Sanghwang Co.,Ltd., Jeju 63243, Korea
}

(Received: February 4, 2017; Revised: June 21, 2017; Accepted: July 14, 2017)

\begin{abstract}
The present study was performed to evaluate the hangover relieving effect of germinated buckwheat (GB) and Sanghwang mushroom mycelium cultured in GB (SGB). Both GB and SGB showed 1,1-diphenyl-2-picrylhydrazyl radical scavenging activities and significantly increased $(p<0.001)$ aldehyde dehydrogenase (ALDH) activities; up to $140 \%$ increase at concentrations of $16 \mu \mathrm{L} / \mathrm{mL}$. Locomotor activity test results from alcohol-SGB and alcohol-GB groups showed improved motor activities over that of the alcohol-water group at $90 \mathrm{~min}$ post-administration. Both alcoholGB and alcohol-SGB groups had significantly reduced $(p<0.001)$ alcohol $(40.02 \pm 33.38 \mu \mathrm{g} / \mathrm{mL}, 66.01 \pm 22.04 \mu \mathrm{g} / \mathrm{mL}$, respectively) and aldehyde $(5.72 \pm 0.47 \mu \mathrm{g} / \mathrm{mL}, 6.72 \pm 1.70 \mu \mathrm{g} / \mathrm{mL}$, respectively) concentrations in blood compared to those in the alcohol-water group $(199.75 \pm 33.83 \mu \mathrm{g} / \mathrm{mL}, 50.43 \pm 13.88 \mu \mathrm{g} / \mathrm{mL}$, respectively) at 90 min post-administration. Based on cDNA microarray analysis, expressions of ALDH genes ALDH1a7 and ALDH18a1 and cytochrome P450 (CY450) gene CYP4a30b were upregulated in the alcohol-GB and alcohol-SGB groups compared to levels in the control group. Overall, the results suggest that both GB and SGB have hangover relieving effects by reducing blood acetaldehyde levels. The molecular mechanisms may involve ALDH activation and upregulated expression of alcohol metabolism-related genes such as ALDH and CYP450.
\end{abstract}

Keywords: Sanghwang mushroom mycelium, aldehyde concentration, germinated buckwheat, hangover relieving effect, locomotor activity test

\section{Introduction}

Alcohol is closely related to human life, and drinking alcohol causes many negative effects on our society and economic growth [1]. Heavy alcohol drinking is associated with many social problems and consequently many studies have focused on addressing alcoholism and relieving hangover [16]. Alcohol and its metabolites damage the liver and cause irreversible liver disease by inducing inflammatory responses during alcohol metabolism [4]. Because alcohol is a molecule capable of permeating all the tissues of the body, it can affect most vital functions. Alcohol metabolism in hepatocytes occurs via three major pathways: alcohol dehydrogenase $(\mathrm{ADH})$ pathway, microsomal ethanol oxidizing system, and catalase [24]. Alcohol is metabolized into acetaldehyde and acetic acid by several liver enzymes including ADH and acetaldehyde dehydrogenase (ALDH), respectively [29]. ALDH oxidizes more than $90 \%$ of acetaldehyde produced from alcohol, transforming acetaldehyde into acetate in a reaction coupled with nicotinamide adenine dinucleotide $\left(\mathrm{NAD}^{+}\right)$reduction
[9]. Acetaldehyde is a primary metabolite produced by oxidizing alcohol which causes hangover symptoms including hot flush, increased pulse, nausea, and vomiting [3, 28]. In addition, acetaldehyde causes functional modulation of proteins [20], glutathione (GSH) depletion, free radical-mediated toxicity and lipid peroxidation [24]. Previous study observed that chronic drinking of reduces ALDH activity [19]. Alcohol intake inhibits antioxidants, and induces oxidative stress by producing oxygen radicals due to increased nicotinamide adenine dinucleotide (NADH) oxidase activity [23], and it causes hepatic cell injury [14].

To investigate functional materials which improve antioxidant activity and alcohol decomposition, a variety of medicinal plants and natural materials have been studied. In particular, various physiological activities of Sanghwang mushroom have been reported including its antioxidant effect [31], anticancer effect [5], and immune-stimulating effect [18]. In addition, germinated buckwheat (GB) has been reported for its antioxidant effect [8], anti-hypertensive and anti-hyperlipidemic effects [21]. In this study, hangover relieving effects

*Corresponding author

Tel: +82-64-754-3378, Fax: +82-64-756-3354

E-mail: chhan@jejunu.ac.kr 
of GB and Sanghwang mushroom mycelium cultivated on GB (SGB) were evaluated through ADH and ALDH activity test, locomotor activity test, blood alcohol and acetaldehyde concentration measurements of mice pre-treated with alcohol. In addition, the differential gene expression patterns in mice liver were analyzed through cDNA microarray analysis to observe the effects of GB or SGB on gene expression related to alcohol metabolism.

\section{Materials and Methods}

\section{Sample preparation}

Sanghwang mushroom mycelium was cultivated on germinated buckwheat for two weeks, and was roasted for 48 hours at $65^{\circ} \mathrm{C}$. Samples and distilled water were mixed in a ratio of $1: 20$, and were distilled above $95^{\circ} \mathrm{C}$ for 3 hours. Extracts were filtered using filter papers, and concentrated using a vacuum concentrator $\left(55 \mathrm{rpm}, 40-45^{\circ} \mathrm{C}\right)$. The concentrations of samples were set to 10 Brix which corresponds to about 10 percent of sugar derivatives in solution, and were used for the experiments.

\section{Experimental animals}

Male BALB/c mice (6 weeks old) were supplied by Orient Bio (Korea). Mice were housed at $24 \pm 1{ }^{\circ} \mathrm{C}$ and $50-55 \%$ humidity under a $12 \mathrm{~h}$ light $/ 12 \mathrm{~h}$ dark cycle for two weeks prior to experiments. All animal experiments were carried out in accordance with the National Institute of Health Guide for the Care and Use of Laboratory Animals and were approved by the Institutional Animal Care and Use Committee of Jeju National University (ACUCC; Approval No. 2016-0007).

\section{1,1-Diphenyl-2-picrylhydrazyl (DPPH) radical scav- enging activities}

The antioxidant activities of GB and SGB extracts were determined by measuring the DPPH free radical scavenging ability of GB and SGB extracts. GB or SGB extracts were dissolved in DMSO separately to make a concentration series (final concentration $0,2,10,4080,120 \mu \mathrm{g} / \mathrm{mL}$ ). $50 \mu \mathrm{L}$ of each sample was mixed with $950 \mu \mathrm{L}$ of $0.2 \mathrm{mM} \mathrm{DPPH}$ (Sigma, USA) solution. The mixture was incubated for 30 min at room temperature in dark condition, and absorbance was measured at $517 \mathrm{~nm}$ using spectrophotometer (Mecasys, Korea). Antioxidant activity was calculated as follows; Antioxidant activity $(\%)=\{1-($ Absorbance of a group added to sample / Absorbance of a group non-added to sample) $\} \times 100$.

\section{ADH/ALDH activities}

ADH activity was measured by using an ethanol quantification assay kit (Megazyme, Ireland) following manufacturer's instructions. Briefly, distilled water $1 \mathrm{~mL}$, buffer $(\mathrm{pH}$ 9.0) plus sodium azide $(0.02 \% \mathrm{w} / \mathrm{v}) 0.1 \mathrm{~mL}, \mathrm{NAD}^{+}$solution $0.1 \mathrm{~mL}$, and $20 \%$ ethanol $10 \mu \mathrm{L}$ were mixed, and then GB and SGB extracts (1, 2, 4, 8, $16 \mu \mathrm{L} / \mathrm{mL}$ of 10 Brix samples) were added separately. Solutions were incubated for $2 \mathrm{~min}$ at room temperature, and absorbance (A1) was measured at $340 \mathrm{~nm}$. Then $10 \mu \mathrm{L}$ ( 1 assay unit) of ADH was added to each mixture, mixtures were incubated for $5 \mathrm{~min}$, and increased absorbance (A2) due to NADH accumulation was measured. ADH activity was represented by relative enzyme activity (\%) to the control group based on the changed absorbance (A2-A1). ALDH activity was also measured by using acetaldehyde quantification assay kit (Megazyme) following manufacturer's protocol.

\section{Locomotor activity test}

The locomotor activity cage (Ugo Basile, Italy) was used to observe the activity of mice. The mice were divided into four groups (10 mice each group), and the three groups were treated with water, GB or SGB $(4 \mathrm{~mL} / \mathrm{kg}) 30$ minutes after alcohol $(2 \mathrm{~mL} / \mathrm{kg})$ treatment. The control group was shamtreated with water at 30 minutes following initial administration of water. Each group of mice was kept in locomotor activity cage $\left(43 \times 43 \times 30(\mathrm{~h}) \mathrm{cm}^{3}\right)$ and their activities in 10minute period were recorded for $990 \mathrm{~min}$ by monitoring infrared beams hit numbers.

\section{Blood alcohol and acetaldehyde concentrations}

The mice were divided into four groups as described above. Then, blood was harvested from each mouse at 90 min post-administration, and blood alcohol and acetaldehyde concentrations were measured. Blood samples were drawn and left at room temperature for $20 \mathrm{~min}$. Serum was separated by centrifugation at $900 \times \mathrm{g}$ for $10 \mathrm{~min}$ and the resulting product was stored at $-70^{\circ} \mathrm{C}$ until use. Blood alcohol concentrations were measured using ethanol quantification assay kit (Megazyme) according to manufacturer's protocol. Briefly, serum $50 \mu \mathrm{L}$, distilled water $1 \mathrm{~mL}$, buffer $(\mathrm{pH} 9.0)$ plus sodium azide $(0.02 \% \mathrm{w} / \mathrm{v}) 0.1 \mathrm{~mL}, \mathrm{NAD}^{+}$solution $0.1 \mathrm{~mL}$ and $25 \mu \mathrm{L}$ (1 assay unit) of ALDH solution were mixed. The solution was incubated for $2 \mathrm{~min}$ at room temperature and absorbance (A1) was measured at $340 \mathrm{~nm}$. After measuring absorbance (A1), $10 \mu \mathrm{L}$ (1 assay unit) of ADH was added to the mixture, and the mixture was incubated for $5 \mathrm{~min}$ and increased absorbance (A2) due to NADH accumulation was measured. Blood alcohol concentrations were calculated using the extinction coefficient of NADH at $340 \mathrm{~nm}$ based on the changed absorbance (A2-A1). Blood acetaldehyde concentration was also measured by using acetaldehyde quantification assay kit (Megazyme) according to the method of Megazyme protocol.

\section{cDNA microarray analysis}

Total RNA was isolated from mice livers (harvested 90 minutes after pretreatment with any intervention) using the Easy-Blue RNA extraction kit (iNtRON Biotechnology, Korea). Transcription of dsDNA was performed by adding the transcription master mix to the dsDNA reaction samples and incubating at $40^{\circ} \mathrm{C}$ for 2 hours. Amplified and labeled cRNA 
was purified on cRNA Cleanup Module (Agilent Technology) according to the manufacturer's protocol. Labeled cRNA target was quantified using ND-1000 spectrophotometer (NanoDrop Technologies, USA). After checking labeling efficiency, fragmentation of cRNA was performed by adding $10 \times$ blocking agent and $25 \times$ fragmentation buffer and incubating at $60^{\circ} \mathrm{C}$ for $30 \mathrm{~min}$. The fragmented cRNA was resuspended with $2 \times$ hybridization buffer and directly pipetted onto assembled Agilent's Mouse Oligo Microarray (44 K). The arrays hybridized at $65^{\circ} \mathrm{C}$ for $17 \mathrm{~h}$ using Agilent Hybridization oven (Agilent Technology). The hybridized microarrays were washed as the manufacturer's washing protocol (Agilent Technology). The hybridized images were scanned using Agilent's DNA microarray scanner and quantified with Feature Extraction Software (Agilent Technology). Functional annotations of genes were performed according to Gene Ontology Consortium [2] by GeneSpringGX 7.3. Gene classification was based on searches done by Medline databases (National Center for Biotechnology Information, USA).

\section{Statistical Analysis}

The one-way analysis of variance (ANOVA) and the Dunnett's test (SPSS 12.0; SPSS, USA) were used to evaluate differences between groups. Results are expressed using descriptive statistics, i.e., the mean $\pm \mathrm{SE}$.

\section{Results}

\section{DPPH radical scavenging activities}

$\mathrm{DPPH}$ radical scavenging activities were measured to observe the antioxidant activities of GB and SGB. The dose response curves of the DPPH radical scavenging activities of GB and SGB were compared over a range from 2 to $120 \mu \mathrm{L} /$ $\mathrm{mL}$. At a concentration of $120 \mu \mathrm{L} / \mathrm{mL}$, the antioxidant activity of GB and SGB was increased to $30 \%$ and $20 \%$ respectively (Fig. 1).

\section{ADH/ALDH activities}

To observe the ADH or ALDH activation ability of GB or $\mathrm{SGB}$, the total enzyme activities were measured in the presence of GB or SGB in vitro. ADH activities were slightly increased up to $110 \%$ by GB or SGB, with no observed significance (Fig. 2A). ALDH activities were increased by GB or SGB in a dose-dependent manner. GB showed a significantly increased $(p<0.001)$ ALDH activity up to $140 \%$ at a concentration of $16 \mu \mathrm{L} / \mathrm{mL}$. In addition, SGB showed significantly increased $(p<0.001)$ ALDH activity up to $139 \%$ at a concentration of $16 \mu \mathrm{L} / \mathrm{mL}$ (Fig. 2B).

\section{Locomotor activity test}

Locomotor activity tests were performed to observe the travel distances of mice treated with alcohol-GB or alcoholSGB. Mice in the control (water-water) group maintained higher locomotor activity compared to the treated groups throughout the time. The alcohol-water group showed mark-

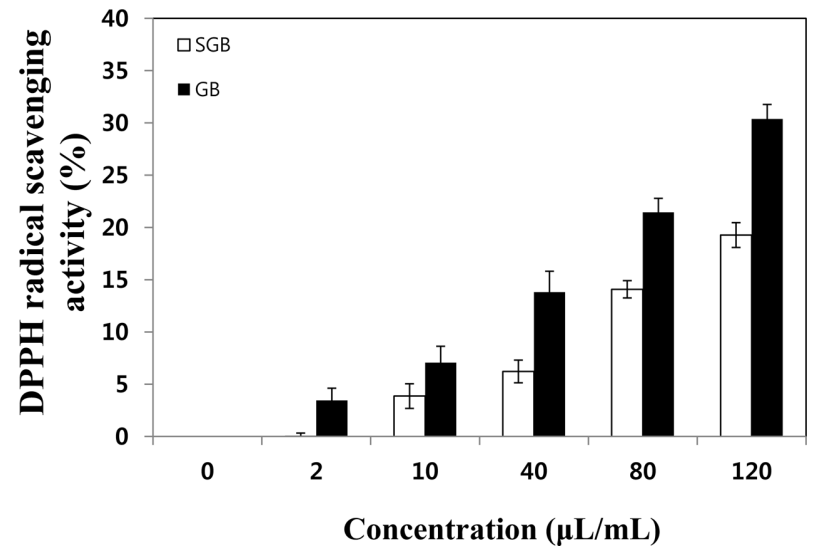

Fig. 1. 1,1-Diphenyl-2-picrylhydrazyl (DPPH) radical scavenging activity followed by different concentrations of germinated buckwheat (GB) and Sanghwang mushroom mycelium cultured by GB (SGB). Values are the means \pm SE of radical scavenging activities $(n=5)$.
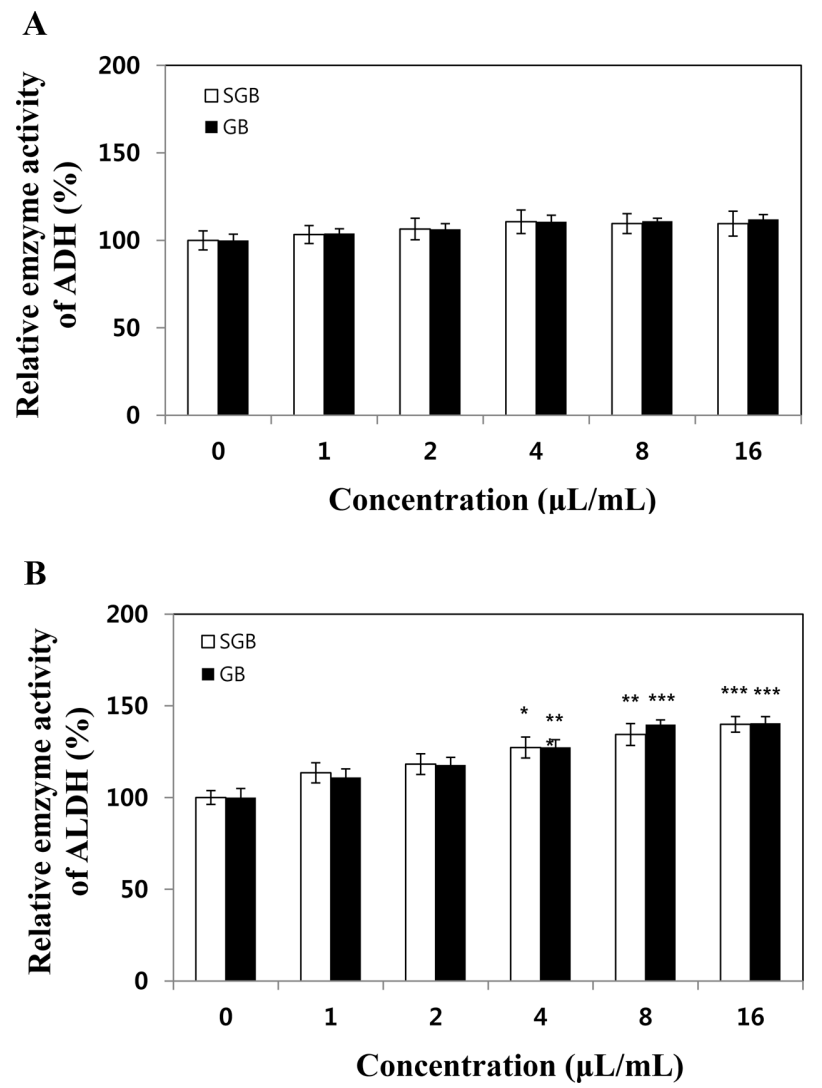

Fig. 2. ADH activation by GB and SGB (A). ALDH activation by GB and SGB (B). The concentration of GB and SGB were set to 10 Brix after extraction, and were used for the experiment. Values are the means \pm SE of relative enzyme activity of control $(\mathrm{n}=5) .{ }^{*} p<0.05,{ }^{* *} p<0.005$ and ${ }^{* * *} p<0.001$ compared to control.

edly decreased locomotor activity at 90 min following treatment. In contrast, the alcohol-GB and alcohol-SGB groups showed more improved locomotor activities compared with the alcohol-water group (Fig. 3). 


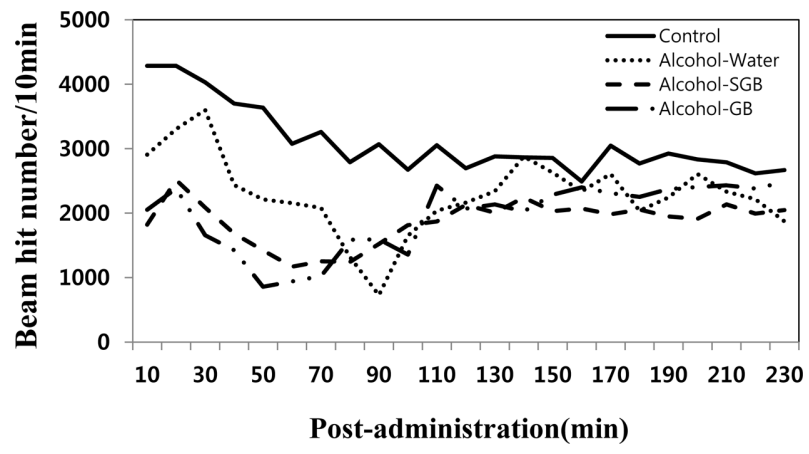

Fig. 3. Locomotor activity of mice administered with GB and SGB. Traveled (ambulatory) distances were measured using a locomotor activity cage with $43 \mathrm{~cm}$ square and $30 \mathrm{~cm}$ height walls. Mice were divided into four groups $(10$ mice each) and three groups were administered with water, GB or SGB at $30 \mathrm{~min}$ after ethanol $(2 \mathrm{~mL} / \mathrm{kg})$ treatment. Control group was administered with water at $30 \mathrm{~min}$ after pre-administration of water. Tests were performed immediately after each administration. Values are means of number of infra-red beams hit during a $10 \mathrm{~min}$ period in each group.

\section{Blood alcohol and acetaldehyde concentrations}

Blood alcohol and acetaldehyde alcohol concentrations were measured at $90 \mathrm{~min}$ after treatment. The alcohol-water group showed a significantly increased blood alcohol level $(199.75 \pm 33.83 \mu \mathrm{g} / \mathrm{mL})$ compared with the control group $(4.78 \pm 0.32 \mu \mathrm{g} / \mathrm{mL})$. Alcohol-SGB group showed a significantly decreased $(p<0.001)$ blood alcohol concentration $(66.01 \pm 22.04 \mu \mathrm{g} / \mathrm{mL})$ compared to the alcohol-water group. In addition, the alcohol-GB group showed a significantly reduced blood alcohol concentration $(40.02 \pm 33.38 \mu \mathrm{g} / \mathrm{mL})$ compared to alcohol-water group (Fig. 4). Alcohol-water group showed a significantly increased blood acetaldehyde concentration $(50.43 \pm 13.88 \mu \mathrm{g} / \mathrm{mL})$ compared with the control group $(5.21 \pm 0.56 \mu \mathrm{g} / \mathrm{mL})$. In contrast, the alcohol-SGB group showed a significantly reduced $(p<0.001)$ blood aldehyde concentration $(6.72 \pm 1.7 \mu \mathrm{g} / \mathrm{mL})$ compared with the alcohol-water group. In addition, alcohol-GB group showed significantly reduced $(p<0.001)$ blood acetaldehyde concentration $(5.72 \pm 0.47 \mu \mathrm{g} /$ $\mathrm{mL}$ ) compared to the alcohol-water group (Fig. 5).

\section{cDNA microarray analysis}

cDNA microarray analysis was performed to observe the differential gene expression in mice liver by alcohol, GB and SGB. Based on the results of cDNA microarray analysis, among 39,429 genes in mouse liver, 523 genes were up-regulated and 1,565 genes were down-regulated in alcohol-GB group compared to alcohol-water group (Table 1). A total of 543 genes and 1,109 genes were up- or down-regulated respectively, in the alcohol-SGB group compared with the alcoholwater group (Table 2). Among the genes involved in alcohol metabolic enzymes, ADH4 and ADHfe genes in ADH family were up-regulated by 1.40 and 1.32 fold respectively, and ALDH1a7 and ALDH18a1 genes in ALDH family were up-

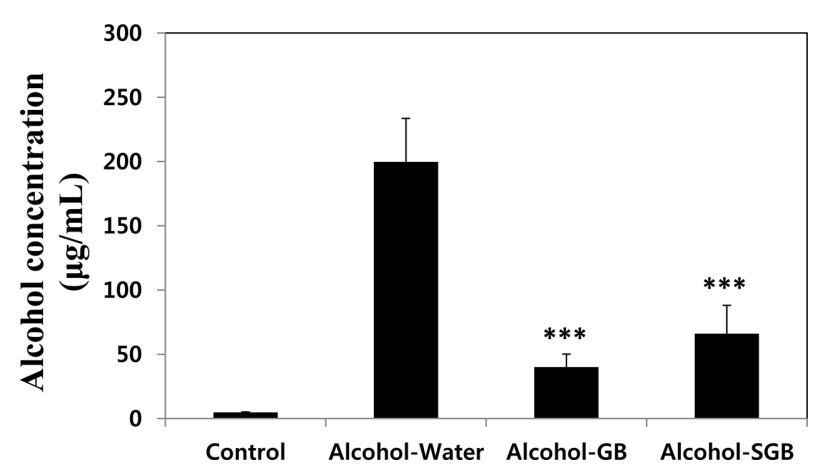

Fig. 4. Alcohol concentrations in the blood of mice administered with GB and SGB. Mice were divided into four groups (10 mice each) and three groups were administered with water $(4 \mathrm{~mL} / \mathrm{kg})$, GB or SGB at $30 \mathrm{~min}$ after alcohol $(2 \mathrm{~mL} / \mathrm{kg})$ treatment. Control group was administered with water at $30 \mathrm{~min}$ after pre-administration of water. Alcohol concentrations were measured at $90 \mathrm{~min}$ after each administration. Values are the means \pm SE of alcohol concentrations. $(* * * p<0.001)$ compared to alcohol-water group.

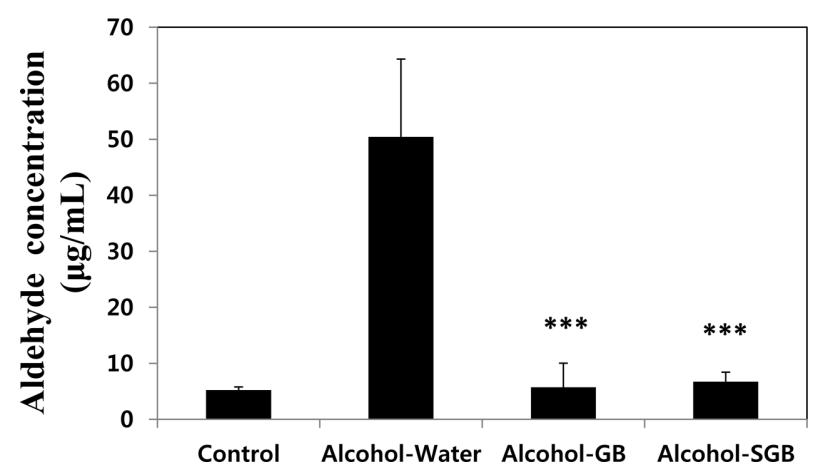

Fig. 5. Aldehyde concentrations in the blood of mice administered with GB and SGB. Mice were divided into four groups (10 mice each) and three groups were administered with water $(4 \mathrm{~mL} / \mathrm{kg}), \mathrm{GB}$ or SGB at $30 \mathrm{~min}$ after alcohol $(2 \mathrm{~mL} / \mathrm{kg})$ treatment. Control group was administered with water at $30 \mathrm{~min}$ after pre-administration of water. Aldehyde concentrations were measured at $90 \mathrm{~min}$ after each administration. Values are the means \pm SE of aldehyde concentrations. $(* * * p<0.001)$ compared to alcohol-water group.

regulated by 2.37 and 1.64 fold in the alcohol-SGB group compared to the alcohol-water group (Table 3). Gene CYP4a30b in cytochrome P450 (CYP450) family was up-regulated by 2.30 and 2.17 fold in alcohol-SGB and alcohol-GB groups respectively (Table 3). In contrast, ALDH1a3 and ALDH3a1 genes in ALDH family were down-regulated by 0.49 and 0.09 fold respectively. CYP2s1, CYP27b1, CYP2j13, CYP24a1, and CYP2j11 genes in CYP450 family were down-regulated by $0.47,0.32,0.14,0.08$ and 0.04 fold respectively in alcohol-SGB group compared to alcohol-water group (Table 4). ALDH1a3 and ALDH3al genes in ALDH family were downregulated by 0.33 and 0.07 fold, and CYP2s1, CYP27b1, CYP2j13, CYP24a1 and CYP2j11 genes in CYP450 family 
Table 3. Up-regulated genes related to the alcohol metabolism by SGB or GB

\begin{tabular}{|c|c|c|c|c|c|c|}
\hline & \multicolumn{2}{|c|}{$\mathrm{ADH}$} & \multicolumn{2}{|c|}{ ALDH } & \multicolumn{2}{|c|}{ Cytochrome P450 } \\
\hline & Gene name & Fold changed & Gene name & Fold changed & Gene name & Fold changed \\
\hline Alcohol-SGB/Alcohol-water & $\begin{array}{l}\text { ADH4 } \\
\text { ADHfe1 }\end{array}$ & $\begin{array}{l}1.40 \\
1.32\end{array}$ & $\begin{array}{l}\text { ALDH1a7 } \\
\text { ALDH18a1 } \\
\text { ALDH1b1 }\end{array}$ & $\begin{array}{l}2.37 \\
1.64 \\
1.53\end{array}$ & $\begin{array}{l}\text { CYP3a44 } \\
\text { CYP2c55 } \\
\text { CYP51 } \\
\text { CYP4a30b }\end{array}$ & $\begin{array}{l}4.60 \\
3.98 \\
2.43 \\
2.30\end{array}$ \\
\hline Alcohol-GB/Alcohol-water & & & & & CYP4a30b & 2.17 \\
\hline
\end{tabular}

ADH, alcohol dehydrogenase; ALDH, aldehyde dehydrogenase.

Table 4. Down-regulated genes related to the alcohol metabolism by SGB or GB

\begin{tabular}{|c|c|c|c|c|c|c|}
\hline & \multicolumn{2}{|c|}{$\mathrm{ADH}$} & \multicolumn{2}{|c|}{ ALDH } & \multicolumn{2}{|c|}{ Cytochrome P450 } \\
\hline & Gene name & Fold changed & Gene name & Fold changed & Gene name & Fold changed \\
\hline \multirow[t]{10}{*}{ Alcohol-SGB/Alcohol-water } & \multirow{10}{*}{-} & \multirow{10}{*}{-} & \multirow{10}{*}{$\begin{array}{l}\text { ALDH1a3 } \\
\text { ALDH3a1 }\end{array}$} & \multirow{10}{*}{$\begin{array}{l}0.49 \\
0.09\end{array}$} & CYP2s1 & 0.47 \\
\hline & & & & & CYP4a14 & 0.43 \\
\hline & & & & & CYP4a31 & 0.41 \\
\hline & & & & & CYP2b13 & 0.38 \\
\hline & & & & & CYP27b1 & 0.32 \\
\hline & & & & & CYP4a32 & 0.26 \\
\hline & & & & & CYP4a10 & 0.19 \\
\hline & & & & & CYP2j13 & 0.14 \\
\hline & & & & & CYP24a1 & 0.08 \\
\hline & & & & & CYP2j11 & 0.04 \\
\hline \multirow[t]{9}{*}{ Alcohol-GB/Alcohol-water } & \multirow{9}{*}{-} & \multirow{9}{*}{-} & \multirow{9}{*}{$\begin{array}{l}\text { ALDH1a3 } \\
\text { ALDH3a1 }\end{array}$} & \multirow{9}{*}{$\begin{array}{l}0.33 \\
0.07\end{array}$} & CYP2s1 & 0.37 \\
\hline & & & & & CYP27b1 & 0.32 \\
\hline & & & & & CYP2j13 & 0.21 \\
\hline & & & & & CYP2c65 & 0.19 \\
\hline & & & & & CYP2c66 & 0.14 \\
\hline & & & & & CYP11a1 & 0.09 \\
\hline & & & & & CYP24a1 & 0.07 \\
\hline & & & & & CYP2j11 & 0.04 \\
\hline & & & & & CYP11b1 & 0.02 \\
\hline
\end{tabular}

were down-regulated by $0.37,0.32,0.21,0.07$ and 0.04 fold in alcohol-GB group compared to the alcohol-water group (Table 4). Based on the results of cDNA microarray analysis, the molecular mechanisms of hangover-relieving may involve up-regulated expression of genes involved in alcohol metabolism, including ALDH and CYP450 genes.

\section{Discussion}

In this study we evaluated the hangover-relieving effects of GB and SGB. Both GB and SGB showed DPPH radical scavenging activities, and showed significantly increased ALDH activities in vitro. In addition, both GB and SGB improved locomotor activities of mice pre-treated with alcohol, and showed a significantly reduced alcohol and aldehyde concentrations in blood compared to alcohol-water group at $90 \mathrm{~min}$ post-administration. In addition, both GB and SGB showed the differential expression of genes related to alcohol metabolism in ALDH and CYP450 gene families. Overall, the results suggest that both GB and SGB have hangover-relieving effects by reducing acetaldehyde levels in the blood. The molecular mechanisms probably involve through up-regulation of ALDH, CYP450 and other genes involved in the metabolism of alcohol.

Enzymatic and non-enzymatic mechanisms exist to protect cells from the internal or external reactive oxygen species supplied by sources such as diet, vitamins, and polyphenols $[22,11]$. Therefore, enhancing protective mechanisms may protect cells against the consequences of oxidative mechanisms delaying the onset of certain conditions including aging and cancer [10, 30]. Accordingly, many studies are focused on relieving hangover, using antioxidant components derived 
from natural products which have no side-effect [27, 33]. In the present study, maximal antioxidant activity of GB and SGB was observed at $30 \%$ and $20 \%$ respectively, which are lower than previous observations [13, 31]. The results indicate that the extract of Sanghwang mushroom mycelium which was cultivated on germinated buckwheat has a lower DPPH radical scavenging activity compared to the extracts from either Sanghwang mushroom or Sanghwang mushroom mycelium which was cultivated on different media.

As observed previously [13], the present study showed that markedly decreased locomotor activity at $90 \mathrm{~min}$ in the alcohol-water group, whereas the alcohol-GB and alcohol-SGB groups showed more improved locomotor activities at 90 min. However, unexpectedly, the alcohol-GB and alcoholSGB groups showed lower locomotor activities than the alcohol-water group until $80 \mathrm{~min}$. The results indicate that the media, germinated buckwheat, might affect to a lower locomotor activity of mice at earlier stage of hangover. Further studies are necessary to evaluate this phenomenon.

The present study showed that ALDH activity was increased up to $140 \%$ by GB or SGB, whereas ADH activity was slightly increased with no observed significance. ADH and ALDH are the principal enzymes responsible for ethanol metabolism. Previous studies showed that ADH and ALDH activities altered by alcohol administration were normalized by dose of Pueraria thunbergiana extracts supplement [12]. ADH4 is a key member of the ADH family. It mainly contributes to liver ADH activity and may account for as much as $40 \%$ of the total ethanol oxidation rate at intoxicating levels of alcohol [32]. The present study showed that the ADH4 gene was up-regulated by 1.4 fold in the alcohol-SGB group compared to the alcohol-water group. The result suggests that hangover relief in the alcohol-SGB group might partially result from increased expression of the $\mathrm{ADH} 4$ gene by the active intervention of SGB. Interestingly, the present study observed that the subfamilies of ALDH1 including ALDH1a7, ALDH1b1 which play a role in detoxification of aldehydes were up-regulated by SGB [26]. In addition, ALDH3a1, which catalyzes the $\mathrm{NAD}(\mathrm{P})^{+}$-dependent oxidation of aromatic and medium chain aldehydes [17], was down-regulated by GB or SGB. Further study is necessary to investigate the role of these subfamilies in alcohol metabolism.

CYP450 is an enzyme superfamily that catalyzes the oxidation of a wide variety of endogenous and exogenous substrates. The present study observed that the CYP4a30b gene, which is known to synthesize 20-hydroxyeicosatetraenoic acid [6], was up-regulated by either GB or SGB. In addition, CYP2c55 gene which catalyzes synthesis of 19-HETE, an arachidonic acid metabolite [15] and the CYP450 sterol 14ádemethylase (CYP51) which is an essential enzyme in the biosynthesis of sterols [7] were up-regulated by SGB. In contrast, CYP2j family members who produce cis-epoxyeicosatrienoic acids, mid-chain $c i s$-transconjugated dienols and $\omega$ terminal alcohols [25] were down-regulated either by GB or SGB. In future studies, the role of CYP $2 j$ family members in alcohol metabolism should be elucidated.

In the present study, the levels of acetaldehyde in the blood of mice at $90 \mathrm{~min}$ pre-administration were inversely proportional to the motor activities of mice, which suggest that improved motor activities of mice were the result of reduced blood acetaldehyde concentration by GB and SGB. cDNA microarray analysis showed that differentially expressed genes associated with alcohol metabolism included ADH, ALDH and CYP450 genes. Overall, the results suggest that both GB and SGB have hangover-relieving effects by reducing acetaldehyde levels in the blood through not only activating ALDH but also up-regulating the expression of the genes associated with alcohol metabolism including ALDH and CYP450. Even though both GB and SGB have hangover-relieving effects for mice, further studies are needed to extrapolate the effectiveness of this topical application to hangover-relieving for human.

\section{Acknowledgments}

This research was supported by the 2016 scientific promotion program funded by Jeju National University, Korea.

\section{References}

1. An SW, Kim YG, Kim MH, Lee BI, Lee SH, Kwon HI, Hwang B, Lee HY. [Comparison of hepatic detoxification activity and reducing serum alcohol concentration of Hovenia dulsis $\mathrm{T}_{\mathrm{HUNB}}$ and Alnus japonica Steud]. Korean J Med Crop Sci 1999, 7, 263-268. Korean.

2. Carbon S, Ireland A, Mungall CJ, Shu S, Marshall B, Lewis S; AmiGO Hub; Web Presence Working Group. AmiGO: online access to ontology and annotation data. Bioinformatics 2009, 25, 288-289.

3. Cha JY, Jung HJ, Jeong JJ, Yang HJ, Kim YT, Lee YS. [Effects of amino acids on the activities of alcohol metabolizing enzyme alcohol dehydrogenase (ADH) and acetaldehyde dehydrogenase (ALDH)]. J Life Sci 2009, 19, 1321-1327. Korean.

4. Choi BT, Choi YH, Gil YG. [Effects of mycelial extract of Phellinus linteus on ethanol-induced liver injury in rats]. J Life Sci 2006, 16, 978-983. Korean.

5. Chung BH, Seo HS, Kim HS, Woo SH, Cho YG. [Antioxidant and anticancer effects of fermentation vinegars with Phellinus linteus, Inonotus obliquus, and Pleurotus ostreatus]. Korean J Med Crop Sci 2010, 18, 113-117. Korean.

6. Eid AA, Gorin Y, Fagg BM, Maalouf R, Barnes JL, Block K, Abboud HE. Mechanisms of podocyte injury in diabetes: role of cytochrome P450 and NADPH oxidases. Diabetes 2009, 58, 1201-1211.

7. Fan J, Urban M, Parker JE, Brewer HC, Kelly SL, Hammond-Kosack KE, Fraaije BA, Liu X, Cools HJ. Characterization of the sterol 14á-demethylases of Fusarium graminearum identies a novel genus-specic CYP51 function. New Phytol 2013, 198, 821-835.

8. Hwang EJ, Lee SY, Kwon SJ, Park MH, Boo HO. [Antioxidative, antimicrobial and cytotoxic activities of Fagopyrum esculentum Möench extract in germinated seeds]. 
Korean J Med Crop Sci 2006, 14, 1-7. Korean.

9. Jelski W, Szmitkowski M. Alcohol dehydrogenase (ADH) and aldehyde dehydrogenase (ALDH) in the cancer diseases. Clin Chim Acta 2008, 395, 1-5.

10. Jung GT, Ju IO, Choi JS, Hong JS. [The antioxidative, antimicrobial and nitrite scavenging effects of Schizandra chinensis Ruprecht (Omija) seed]. Korean J Food Sci Technol 2000, 32, 928-935. Korean.

11. Kim EH, Rhee DK. [Anti-oxidative properties of ginseng]. J Ginseng Res 2009, 33, 1-7. Korean.

12. Kim MJ, Lee JS, Ha OM, Jang JY, Cho SY. [Effects of Pueraria thunbergiana Bentham water extracts on hepatic alcohol metabolic enzyme system in rats]. J Korean Soc Food Sci Nutr 2002, 31, 92-97. Korean.

13. Kim MS, An YJ, Lee JC, Park GR, Park DS, Jeon NG, Lee Y, Han CH. [Hangover relieving effect of Sanghwang mushroom mycelium extract]. Korean J Vet Res 2016, 56, 241-247. Korean.

14. Kim Y, Woo H. [Protective effects of Yinjinchunggan-tang (YJCGT) on alcohol-induced oxidative stress]. J Korean Orient Intern Med 2011, 32, 550-564. Korean.

15. Kono Y, Kamino H, Moore R, Lih F, Tomer KB, Zeldin DC, Goldstein JA, Negishi M. The nuclear receptors constitutive active/androstane receptor and pregnane $\mathrm{X}$ receptor activate the Cyp2c55 gene in mouse liver. Drug Metab Dispos 2010, 38, 1177-1182.

16. Koo BK, Chung JM, Lee HS. [A study on the alcohol consumption and nutrient intake in patients with alcoholic liver disease]. J Nutr Health 1997, 30, 48-60. Korean.

17. Lassen N, Pappa A, Black WJ, Jester JV, Day BJ, Min E, Vasiliou V. Antioxidant function of corneal ALDH3A1 in cultured stromal fibroblasts. Free Radic Biol Med 2006, 41, 1459-1469.

18. Lee BE, Ryu SY, Kim EH, Kim YH, Kwak KA, Song HY. [Immunostimulating effect of mycelium extract of Phellinus linteus]. Korean J Pharmacol 2012, 43, 157-162. Korean.

19. Lee JH, Kim NK, Lee DY, Lee CH. [Protective effect of selected amino acids and food extracts on ethanol toxicity decrement in rat liver]. Korean J Food Sci Technol 1999, 31, 802-808. Korean.

20. Lee, JH, Park KS. [Effect of Ganoderma lucidum on the liver function and lipid metabolism in alcohol consuming rats]. Korean J Nutr 1999, 32, 519-525. Korean.

21. Lee JS, Park SJ, Sung KS, Han CK, Lee MH, Jung CW,
Kwon TB. [Effects of germinated-buckwheat on blood pressure, plasma glucose and lipid levels of spontaneously hypertensive rats]. Korean J Food Sci Technol 2000, 32, 206-211. Korean.

22. Lee KA, Chung HY. [Biological activities of a Korean traditional prescription, Nogyongdaebotang]. J Korean Soc Food Sci Nutr 2004, 33, 28-33. Korean.

23. Lee SJ, Kim A, Lee JH, Kim MH, Lee BS, Jee YT, Bin JH, Ha JM. [Effects of minerals added to medicinal plant extracts on alcohol-induced oxidative stress and alcohol metabolism in rats]. J Korean Soc Food Sci Nutr 2011, 40, 393-400. Korean.

24. Lieber CS. Ethanol metabolism, cirrhosis and alcoholism. Clin Chim Acta 1997, 257, 59-84.

25. Messina A, Nencioni S, Gervasi PG, Gotlinger KH, Schwartzman ML, Longo V. Molecular cloning and enzymatic characterization of sheep CYP2J. Xenobiotica 2010, 40, 109118.

26. Muzio G, Maggiora M, Paiuzzi E, Oraldi M, Canuto RA. Aldehyde dehydrogenases and cell proliferation. Free Radic Biol Med 2012, 52, 735-746.

27. Oh SI, Lee MS. [Antioxidative and antimutagenic effects of Ganoderma lucidum Krast extracts]. Korean J Food Nutr 2005, 18, 54-62. Korean.

28. Park EM, Ye EJ, Kim SJ, Choi HI, Bae MJ. [Eliminatory effect of health drink containing Hovenia dulcis Thunb extract on ethanol-induced hangover in rats]. J Korean Soc Food Cult 2006, 21, 71-75. Korean.

29. Peters TJ. Ethanol metabolism. Br Med Bull 1982, 38, 1720.

30. Rha YA, Choi MS, Park SJ. [Antioxidant and antiadipogenic effects of fermented Rhus verniciflua]. Korean $\mathbf{J}$ Culin Res 2014, 20, 137-147. Korean.

31. Rhyu DY, Kim MS, Min OJ, Kim DW. [Antioxidative effects of Phellinus linteus extract]. Korean J Plant Resour 2008, 21, 91-95. Korean.

32. Wei RR, Zhang MY, Rao HL, Pu HY, Zhang HZ, Wang HY. Identification of ADH4 as a novel and potential prognostic marker in hepatocellular carcinoma. Med Oncol 2012, 29, 2737-2743.

33. Yoon BR, Cho BJ, Lee H, Kim DJ, Rhee SK, Hong H, Kim KT, Cho CW, Choi HS, Lee BY, Lee OH. [Antioxidant and anti-adipogenic effects of ethanolic extracts from tartary and common buckwheats]. Korean $\mathrm{J}$ Food Preserv 2012, 19, 123-130. Korean. 